\title{
Livestock Impacts on Riparian Ecosystems and Streamside Management Implications... A Review
}

\section{J. BOONE KAUFFMAN AND W.C. KRUEGER}

Historically, riparian vegetation has been defined as vegetation rooted at the water's edge (Campbell and Franklin 1979). Quite often, however, the stream influences vegetation in many ways and well beyond the water line. In lotic systems, the stream is not only responsible for increased water availability, but also for the soil deposition, unique microclimate, increased productivity, and the many consequential, self-perpetuating biotic factors associated with riparian zones. These factors all contribute in the formation of a unique assemblage of plant communities quite distinct from upland communities surrounding the riparian zone. Therefore, along streambanks, other lotic systems, and even ephemeral drainages, riparian ecosystems could best be defined as those assemblages of plant, animal, and aquatic communities whose presence can be either directly or indirectly attributed to factors that are stream-induced or related (Kauffman 1982).

Riparian zones can vary considerably in size and vegetation complexity because of the many combinations that can be created between water sources and physical characteristics of a site (Odum 1971, Platts 1979, Swanson et al. 1982). Such characteristics, include gradient, aspect, topography, soil type of streambottom, water quality, elevation, and plant community (Odum 1971). However, riparian zones, particularly those bordering streams or rivers, have several characteristics in common. They are ecotonal, with high edge to area ratios (Odum 1978). As functional ecosystems they are very open with large energy, nutrient, and biotic interchanges with aquatic systems on the inner margin (Cummins 1974, Odum 1978, Sedel et al. 1974) and upland terrestrial ecosystems on the other margin (Odum 1978).

Thomas et al. (1979) stated that all riparian zones within managed rangelands of the western United States have the following in common: (1) they create well-defined habitat zones within the much drier surrounding areas; (2) they make up a minor proportion of the overall area; (3) they are generally more productive in terms of biomass - plant and animal - than the remainder of the area; and (4) they are a critical source of diversity within rangelands. Both density and diversity of species tends to be higher at the

\footnotetext{
Authors are former graduate research assistant and professor, Department of Rangeland Resources, Oregon State University, Corvallis, respectively.

This article is submitted as Technical Paper No. 6867. Oregon Agriculture Experiment Station, Corvallis.

Manuscript accepted January 23, 1984.
}

land/water ecotones than in adjacent upland, especially where regional climates are characterized by dry periods (Odum 1978). Ganskopp (1978) described 44 vegetation communities in a 49hectare riparian zone in the Blue Mountains of northeastern Oregon. Kauffman et al. (1984) stated that the several biotic, environmental and other abiotic factors interacting in a riparian zone in Oregon created a disproportionately greater number of niches compared to surrounding upland ecosystems. Two-hundred and fifty-eight stands of vegetation representing 60 discrete plant communities were identified within this study area. The higher diversity, productivity, and other unique factors associated with the riparian zone when compared to the surrounding uplands are the primary factors that create the importance of these areas as focal points for the management of the livestock, fishery, and wildlife resources.

\section{Importance of Riparian/Stream Ecosystems}

\section{Importance to Instream Ecosystems}

Vegetation along small streams is an important component of the riparian/stream ecosystem (Campbell and Franklin 1979, Jahn 1978). Riparian vegetation produces the bulk of the detritus that provides up to $90 \%$ of the organic matter necessary to support headwater stream communities (Cummins and Spengler 1978). In these tributaries of forest ecosystems $99 \%$ of the stream energy input may be imported from bordering riparian vegetation (i.e., it is heterotrophic) and only $1 \%$ derived from stream photosynthesis by attached algae (periphyten) and mosses (Cummins 1974). Berner (in Kennedy 1977) found that even in large streams such as the Missouri River, $54 \%$ of the organic matter ingested by fish is of terrestrial origin. The riparian zone vegetation functions both in light attenuation and as the source of allochthonous inputs, including long-term structural and annual energy supplies (Cummins 1974).

Vegetation along streams exercises important controls over physical conditions in the stream environment. It acts as a roughness element that reduces the velocity and erosive energy of overbank flow during floods ( $\mathrm{Li}$ and Shen 1973). The result is a higher flood peak than a channel without riparian vegetation but lower erosional factors acting on the floodplain and bank (Schumm and Meyer 1979). Healthy riparian vegetation tends to stabilize 
streambanks, determines bank morphology and may help reduce streambank damage from ice, log debris, and animal trampling (Platts 1979, Swanson et al. 1982).

Channel and floodplain obstructions such as branches, logs, and rocks enhance detention and concentration of organic matter, thereby facilitating its use locally rather than washing downstream (Everest and Meehan 1981, Jahn 1978, Swanson et al. 1982). In addition, wood debris in channel bottoms appears to play an important role in the dynamics of stream morphology. Large pieces of woody debris in streams dissipate stream energy, control routing of sediment and water through channel systems, and serve as substrates for biological activity by microbial and invertebrate organisms (DeBano 1977, Swanson et al. 1982).

Streamside vegetation strongly influences the quality of habitat for anadromous and resident coldwater fishes (Duff 1979, Everest and Meehan 1981, Marcuson 1977, Meehan et al. 1977). Riparian vegetation provides shade, preventing adverse water temperature fluctuations (Meehan et al. 1977). The roots of trees, shrubs, and herbaceous vegetation stabilize streambanks, providing cover in the form of overhanging banks (Marcuson 1977, Meehan et al. 1977). Streamside vegetation acts as a "filter" to prevent sediment and debris from man's activities from entering the stream (Meehan et al. 1977). Riparian vegetation also directly controls the food chain of the ecosystem by shading the stream and providing organic detritus and insects for the stream organisms (Cummins 1974, Meehan et al. 1977).

\section{Importance to Wildlife}

It is believed that, on land, the riparian/stream ecosystem is the single most productive type of wildlife habitat, benefiting the greatest number of species (Ames 1977, Hubbard 1977, Miller 1951, Patton 1977). The riparian zone provides an almost classic example of the ecological principles of edge effect (Odum 1978). Riparian habitat provides living conditions for a greater variety of wildlife than any other types of habitat found in California (Sands and Howe 1977), the Great Basin of southeast Oregon (Thomas et al. 1979), the Southwest (Hubbard 1977), the Great Plains (Tubbs 1980), and perhaps the entire North American continent (Johnson et al. 1977).

Examples of the wildlife values of riparian habitat are numerous (Carothers et al. 1974, Carothers and Johnson 1975, Henke and Stone 1978, Hubbard 1977, Thomas et al. 1979). Hubbard (1977) reported that $16-17 \%$ of the entire breeding avifauna of temperate North America occurs in 2 New Mexico river valleys over the course of a "few score" miles. Johnson et al. (1977) reported that $77 \%$ of the 166 nesting species of birds in the Southwest are in some manner dependent on water related (riparian) habitat and $50 \%$ are completely dependent on riparian habitats. In western Montana, $59 \%$ of the land bird species use riparian habitats for breeding purposes and $36 \%$ of those breed only in riparian areas (Mosconi and Hutto 1982). Thomas et al. (1979) stated that of the 363 terrestrial species known to occur in the Great Basin of southeastern Oregon, 299 are either directly dependent on riparian zones or utilize them more than any other habitats.

When riparian vegetation is eliminated, several wildlife species dependent on riparian ecosystems may be either severely reduced or may disappear altogether. Henke and Stone (1978) found $93 \%$ fewer bird numbers and $72 \%$ fewer avian species on 2 riprapped plots from which riparian vegetation had been removed, and $95 \%$ fewer birds and $32 \%$ fewer species on cultivated lands previously occupied by riparian forests.

The influence of riparian ecosystems on wildlife is not limited to those animal species that are restricted in distribution to the streamside vegetation. Population densities of birds in habitats adjacent to the riparian type are influenced by the presence of a riparian area (Carothers 1977 ). When a riparian habitat is removed or extensively manipulated, not only are the riparian species of the area adversely influenced, but wildlife productivity in the adjacent habitat is also depressed (Carothers 1977).
Riparian ecosystems are valuable to wildlife as a source of water, food, and cover (Stevens et al. 1977, Thomas et al. 1979). They also provide nesting and brooding habitat for avian species (Carothers et al. 1974, Johnson et al. 1977, Tubbs 1980). By furnishing abundant thermal cover and favorable micro-climates, especially when surrounded by nonforested ecosystems, they facilitate the maintenance of of homeostatis, particularly for big game (Thomas et al. 1979). Riparian ecosystems also serve as big game migration routes between summer and winter range (Thomas et al. 1979), and provide routes and nesting cover for migrating avian species (Stevens et al. 1977, Wauer 1977).

\section{Importance to Livestock}

Livestock grazing on rangelands is the most extensive form of land use in the interior Pacific Northwest (Skovlin et al. 1977). Cattle tend to congregate on meadows and utilize the vegetation much more intensively than the vegetation of adjacent ranges (Reid and Pickford 1946).

In northeast Oregon, Reid and Pickford (1946) stated that moist meadow soils in riparian ecosystems are generally so highly productive than an acre of mountain meadow has a potential grazing capacity equal to 10-15 acres of forested range. Although riparian meadows cover only about $1-2 \%$ of the summer range area of the Pacific Northwest, potentially they can produce $20 \%$ of the summer range forage (Reid and Pickford 1946, Roath and Krueger 1982). However, Roath and Krueger (1982) found that because of livestock concentrations, limits on livestock movements imposed by steep slopes, and erratic distribution of watering areas away from the creek, the riparian zone (covering about $2 \%$ of a Blue Mountain grazing allotment) accounted for $81 \%$ of the total herbaeous vegetation removed by cattle.

Cattle exhibit a strong preference for riparian zones for a number of the same reasons other animals prefer and use these areas. The main attributes believed to attract and hold cattle to riparian areas are the availability of water, shade, and thermal cover, and the quality and variety of forage (Ames 1977, Severson and Boldt 1978). In addition, sedges (Carex spp.) tend to retain relatively constant crude protein levels until the first killing frost. Several sedges common to riparian zones of the Pacific Northwest outrank key upland forage species in sustained protein and energy content (McLean et al. 1963, Paulsen 1969, Skovlin 1967).

\section{Livestock Riparian Relationships}

The impact of livestock on riparian zones in public grazing lands of the western states has received much attention recently. Several studies are presently underway examining the impact of livestock grazing on stream ecology, water quality, channel stabilization , salmonid fish habitat and physiology, terrestrial riparian wildlife populations, and riparian vegetation.

It is often difficult for one to interpret science from opinion in the literature. Many of the studies reported in this paper have not necessarily followed the generally accepted "scientific method"for research today. However, it is not the purpose of this paper to determine, even if possible, which published reports represent quality scientific results and which are little more than a forum to express one's opinion. Rather the purpose of this paper is to familiarize the reader with the accepted facts and management theories available today concerning livest ock interactions in riparian zones with the other valid resources also dependent or utilizing this resource. Where possible, in this paper, results of properly conducted research are reported using terms such as "significant", referring to a statistically significant result and those of reports relying on observational data or "hearsay" will be reported as suggestions or observations.

General Considerations for Livestock-Riparian Management

The quality of the riparian habitat and its associated aquatic environment, both formed over geologic time, are fragile ecosystems which currently serve as focal points for management of 
livestock, recreation, and fisheries and timber resources. It has been reported that inappropriate livestock management results in overuse and subsequent degradation of the riparian/stream ecosystem (Behnke and Raleigh 1978, Oregon-Washington Interagency Wildlife Council 1978, Platts 1979). Davis (1982) suggested that one of the most destructive forces in riparian ecosystems is the long-term impact of overgrazing by cattle. Livestock grazing can affect 4 general components of an aquatic system-streamside vegetation, stream channel morphology, shape and quality of the water column and the structure of the soil portion of the streambank (Behnke and Raleigh 1978, Marcuson 1977, Platts 1979, Platts 1981). Improper livestock use of riparian ecosystems can affect the streamside environment by changing, reducing, or eliminating vegetation bordering the stream (Ames 1977, Behnke and Raleigh 1978, Platts 1979). The channel morphology can be changed by widening and shallowing of the streambed, gradual stream channel trenching, or braiding, depending on soils and substrate composition (Behnke and Raleigh 1978, Gunderson 1968, Marcuson 1977, Platts 1979). The water column can be altered by increasing water temperatures, nutrients, suspended sediments, bacterial counts and by altering the timing and volume of water flow (Behnke and Raleigh 1978, Johnsen et al. 1978, Rauzi and Hanson 1966, Platts 1979). Overgrazing can cause bank sloughoff creating false setback banks, accelerated sedimentation, and subsequent silt degradation of spawning and food producing areas (Behnke and Raleigh 1978, Everest and Meehan 1981, Platts 1979, Platts 1981). These impacts on the water column due to abusive livestock practices result in decreased fish biomass and in percent of salmonid fishes in the total fish composition (Behnke and Raleigh 1978, Bowers et al. 1979, Duff 1979, Gunderson 1968, Marcuson 1977).

Livestock abuse of riparian areas can severely impact terrestrial wildlife habitat causing a subsequent decrease in wildlife species and numbers (Ames 1977, Townsend and Smith 1977, Tubbs 1980 , Wiens and Dyer 1975).

Improper grazing can have a considerable effect on vegetation, resulting in decreased vigor, biomass and an alteration of species composition and diversity (Ames 1977, Bryant et al. 1972, Evans and Krebs 1977, Knoph and Cannon 1982, Pond 1961).

While various other land management activities have caused serious losses or reductions in wildlife habitat productivity, livestock grazing has been suggested as the major factor identified in numerous studies throughout the 11 western states (OregonWashington Interagency Wildlife Council 1978). Conversely, Busby (1979) suggested that it was not reasonable to conclude that livestock grazing is the only, nor necessarily the major cause of impacts to riparian ecosystems.

\section{Impacts of Livestock on the Instream Ecology}

A healthy instream environment is vital for the aquatic life forms inhabiting the stream, as well as for various human needs that directly depend on water quality. High concentrations of suspended solids or other sediment loads, and fecal coliforms or fecal streptococci are usually associated with the degree of impact of man's activities, and can have a major impact in altering an existing stream ecosystem or even creating an entirely new ecosystem (Johnson et al. 1977, Johnson et al. 1978, McKee and Wolf 1963).

During the grazing season, Johnson et al. (1978) could not find any significant differences in physical and chemical properties of streamwater (suspended solids, total dissolved solids, and orthophosphates) between an area grazed at $1.2 \mathrm{ha} / \mathrm{AUM}$ and an ungrazed area. After the grazing season, however, there was a significant increase in total dissolved solids which indicated that some livestock waste products may have eventually reached and enriched the stream, probably from the action of rain showers. The presence of cattle significantly elevated the fecal coliform and fecal streptococci for about 9 days after cattle were removed.

Winegar (1977) found sediment loads were reduced $48-79 \%$ while flowing through 3.5 miles of a stream protected from grazing.

Rauzi and Hanson (1966) found a nearly linear relation between runoff and infiltration to the degree of grazing intensity. They found that runoff from a heavily grazed watershed $(1.35$ acre/AUM) was 1.4 times greater than from a moderately grazed watershed ( 2.42 acre / $A U M$ ) and 9 times greater than from a lightly grazed watershed (3.25 acre/AUM).

Changes in water temperature have been shown to have drastic effects on fisheries and aquatic insect populations (Johnson et al. 1977). Changes in average temperature or daily fluctuations can in effect create an entirely new aquatic ecosystem (Johnson et al. 1977).

Van Velson (1979) found average water temperatures dropped from $24^{\circ} \mathrm{C}$ to $22^{\circ} \mathrm{C}$ after 1 year of livestock exclusion on a creek in Nebraska. Claire and Storch (unpublished) compared stream temperatures between an area that had been grazed season long (June 1-October 15) and an area that had been rested for 4 years and, thereafter, grazed only after August 1. The maximum water temperatures outside and downstream from the exclosure averaged $7^{\circ} \mathrm{C}$ higher than those sampled within the exclosure. Daily fluctuations of water temperatures averaged $15^{\circ} \mathrm{C}$ outside the exclosure as compared to $7^{\circ} \mathrm{C}$ inside the exclosures. Winegar (pers. comm. 1982) observed similar results in an exclosure along Beaver Creek in central Oregon.

The effects of livestock grazing have been shown to vary greatly depending upon several factors, in particular, the nature of the stream studied. Duff (1979) stated that introduction of livestock for 6 weeks into a riparian area rested for 4 years resulted in elimination of overhanging banks and a fracturing of the streambank, causing it to erode into the stream. In contrast, after 6 weeks of mid-summer grazing by cattle, Roath (1980) gave a visual estimate of $90 \%$ bank stability with little indication that trampling was contributing to or causing erosion. He attributed nearly all erosion present to geologic erosion caused by the actions of streamflow.

Buckhouse et al. (1981) could find no particular relationship between streambank erosion and various grazing treatments (including nonuse) in northeastern Oregon. There appeared to be no significant patterns of accelerated streambank deterioration due to moderate livestock grazing (3.2 ha/AUM and 60-65\% utilization of the riparian vegetation). Most bankcutting losses in this system were associated with over-winter periods where ice floes, high water, and channel physiognomy were critical factors involved in the erosional process.

Hayes (1978) found that stream channel movement did not occur more frequently in grazed riaprian meadows under a restrotation grazing scheme compared to ungrazed meadows after 1 year of study. Rather, streambank degradation appeared to occur more often and to a greater magnitude along ungrazed streams. However, Hayes stated that sloughoff increased as forage removal was above $60 \%$. High forage removal, high amount of foraging time along banks, and high percentages of palatable sedges along the bank were shown to significantly increase the probability of sloughoff occuring during the grazing season.

Kauffman et al. (1983b) measured significantly greater streambank losses in grazed areas (1.3-1.7 ha/AUM) compared to ungrazed areas in northeastern Oregon. The grazed pastures had utilization levels greater than $35 \%$ and less than $85 \%$ on the different vegetation stands while utilization by native animals was less than $20 \%$ on every stand. During 2 late season grazing periods (late August-mid-September), a mean of $13.5 \mathrm{~cm}$ of streambank was lost in grazed areas and $3.0 \mathrm{~cm}$ was lost in ungrazed areas. Total annual streambank losses were $30 \mathrm{~cm}$ in grazed areas and $9 \mathrm{~cm}$ in ungrazed areas.

Marcuson (1977) found the average channel width to be 53 meters in an area grazed season long at $0.11 \mathrm{ha} / \mathrm{AUM}$ and an average channel width of only 18.6 meters in areas that were ungrazed. Marcuson (1977) also recorded 224 meters of undercut bank / $\mathrm{km}$ in the grazed area and 686 meters of undercut bank $/ \mathrm{km}$ in the ungrazed area. Heavy grazing and trampling by cattle were suggested to cause the excessive erosion. 
Duff (1979) found the stream channel width in a grazed area was $173 \%$ greater than the stream channel not grazed for 8 years inside an exclosure. Similar results have been reported (Behnke and Zarn 1976, Dahlem 1979, Gunderson 1968, Heede 1977) where overgrazing and excessive trampling caused a decrease in bank undercuts, increases in channel widths, and a general degradation of fish habitat.

Claire and Storch (unpublished) stated that the production of game fish in headwater streams can be used as a biological indicator of the quality of land management that is occurring within the watershed and/or streamside. Overgrazing, causing a reduction in vegetative cover and the caving in of overhanging banks, has been suggested as one of the principal factors contributing to the decline of native trout in the West (Behnke and Zarn 1976).

Bowers et al. (1979) reported an average increase in fish production of $184 \%$ for 5 independent studies where livestock use was light or eliminated by fencing. They concluded with a prediction that trout production in streams currently being heavily grazed could be increased about $200 \%$ if management decisions were made to optimize habitat conditions for trout.

Van Velson (1979) found rough fish made up $88 \%$ of a fish population before relief from grazing and only $1 \%$ of the population after 8 years' rest. Rainbow trout (Salmo gairdneri) made up $1 \%$ of the fish population before cessation of grazing and $97 \%$ of the population after relief from grazing. Marcuson (1977) found that an overgrazed section (.11 ha/AUM) of Rock Creek, Montana, supported only $71 \mathrm{~kg}$ of brown trout (Salmo trutta) per hectare; whereas an ungrazed section produced $238.8 \mathrm{~kg}$ of brown trout per hectare. Claire and Storch (unpublished) found in the Blue Mountains of Oregon that game fish were $24 \%$ of the total population in area grazed season long, contrasted to a $77 \%$ game fish composition within a livestock exclosure.

Chapman and Knudsen (1980) found 8 sections of streamside vegetation in western Washington, judged to be moderately to heavily affected by livestock, had significant reductions in total biomass for Coho salmon (Oncorhychus kisutch). Cutthroat trout (Salmo clarki), and all salmonids compared to those areas that had not been grazed. Similar relationships between livestock grazing and salmonid fish populations have been reported by Dahlem (1979), Duff (unpublished), Gunderson (1968), Keller et al. (1979), and Lorz (1974).

\section{Impacts of Livestock on Terrestrial Wildlife}

Riparian zones are the most critical wildlife habitats for many species in managed rangelands (Thomas et al. 1979). It is readily apparent that riparian ecosystems are of paramount importance in producing and maintaining a large degree of biotic diversity in North America (Hubbard 1977, Johnson et al. 1977).

Changes in plant vigor, growth form and species composition due to grazing have frequently been related to the increase or decline of various species of birds (Townsend and Smith 1977). Several studies have shown a negative impact on certain avian populations due to grazing (Dambach and Good 1940, Overmire 1963, Owens and Meyers 1973, Reynolds and Trost 1980, Smith 1940). The tendency for livestock to congregate and linger around ponds and streambanks may result in the elimination of food and cover plants and reduces nest sites and habitat diversity (Buttery and Shields 1975, Behnke and Raleigh 1978, Crouch 1978, Evans and Krebs 1977). However, grazing may improve habitat for some avian species (Burgess et al. 1965, Crouch 1982, Kirch and Higgins 1976). In areas of higher precipitation (or productivity), grazing may be highly desirable to open up "roughs" and provide more diversity and patchiness (Ryder 1980). Grazing effects on breeding avifaunas are not uniform nor easily defined, primarily because grazing varies so much in its local intensity and because of the general difficulties in unraveling cause-effect relationships in rangeland faunas (Wiens and Dyer 1975).

Several studies have shown wildlife numbers increased when a riparian area that was abused by improper grazing practices was fenced and allowed to recover (Crouch 1978, 1982, Duff 1979, Van Felson 1979, Winegar 1977). Duff (1979) reported a 350\% increase in small mammal songbird and raptor use after 8 years' rest from grazing. Van Velson (1979) reported increased pheasant (Phasianius colchicus) production, increased deer populations, and that watefowl production occurred for the first time in the rested area. Crouch (1982) found more ducks (primarily mallards) (Anas platyrhynchos), more upland game animals, and twice as many terrestrial birds in an ungrazed bottomland rested for 7 years compared to adjacent grazed bottomlands on the South Platte River in northeastern Colorado. The grazed areas, utilized at "varying intensitics, provided habitat for significantly morc aquatic species of birds.

Mosconi and Hutto (1982) found no significant differences in total bird densities between heavily grazed riparian communities ( 2.5 cow-calf units/ha) and lightly grazed riparian communities ( 0.3 cow-calf units $/$ ha). However, significant differences were recorded in bird species composition and foraging guilds. The majority of the bird species significantly affected were of the flycatcher, ground-foraging thrust, or foliage-gleaning insectivore guilds.

Similar results were reported by Kauffman (1982) and Kauffman et al. (1982). No significant differences in total avian densities were noted between riparian communities grazed under a lateseason grazing scheme (2.0-2.5 ha/AUM) and those totally excluded from grazing. However, forage removal causing a change in habitat physiognomy did appear to cause some differential use in species and foraging guilds. These differences were particularly evident immediately after forage removal and negligible during seasons when cover and plant growth were similar between treatments. The grazed riparian communities were preferred by birds of insect foraging guilds; ungrazed riparian communities were preferred by birds of herbivorous/granivorous foraging guilds.

Livestock grazing and the subsequent removal of forage in the riparian zone has been shown to cause significant short-term decreases in small mammal composition and densities (Kauffman et al. 1982). When mammal densities before and after the grazing season in 1979 (stocking rate of 2.0-2.5 ha/ AUM) were compared, small mammal communities decreased from 800 to 83 mammals/ha in Douglas hawthorn (Crataegus douglasii)-dominated communities; from 450 to $60 \mathrm{mammals} / \mathrm{ha}$ in riparian meadow communities; and from 129 to 42 mammals/ha in black cottonwood (Populus trichocarpa)-mixed conifer communities. By late summer the following year ( 10 months after grazing) and just prior to the grazing season, small mammal densities were not significantly different between grazed and ungrazed areas.

When properly managed, the grazing of domestic livestock is generally compatible with wildlife, and may even increase the numbers of some species (Tubbs 1980). Nongame wildlife which depend on riparian ecosystems have intangible values which are very hard to evaluate (Peterson 1980). It has been demonstrated that livestock can graze streamsides without causing serious damage, and the capability to achieve positive on-site livestock control appears to be the limiting factor (Claire and Storch unpublished).

\section{Impacts of Livestock on Riparian Vegetation}

Recently there has been much published research and opinion on the effects of livestock in riparian ecosystems. Specifically, these reports have dealt with soil compaction and its relationship to root growth; plant succession and productivity; and species diversity and vegetation structural diversity. Opinions on the subject have varied from there being no evidence of heavy, season-long cattle grazing affecting the productivity of a riparian zone, or causing bank deteriorations by trampling (Roath 1980 ) to grazing only a few days seriously impairing a riparian zone's reproductive capability.

Impacts to riparian vegetation induced by livestock can basically be separated into: (a) compaction of soil, which increases runoff and decreased water availability to plants; (b) herbage removal, 
which allows soil temperatures to rise and increases evaporation to the soil surface; and (c) physical damage to vegetation by rubbing, trampling, and browsing (Severson and Boldt 1978).

\section{Impacts of Trampling}

The impact of livestock trampling on soil compaction bulk density and subsequent effects on forage growth have been documented. Alderfer and Robinson (1949), Bryant et al. (1972), Orr (1960), and Rauzi and Hanson (1966) all found soil compaction increased linearly with increases in grazing intensity.

Alderfer and Robinson (1949) found grazing and trampling Kentucky bluegrass (Poa pratensis) upland pastures to a 1 -inch $(2.5 \mathrm{~cm})$ stubble height reduced vegetation cover, lowered yields, decreased noncapillary porosity, and increased the volume weight of the $0-1$ inch $(0-2.5 \mathrm{~cm})$ layer of soil.

Rauzi and Hanson (1966) found water intake rates on silty clay and silty clay loam soils to be 2.5 times greater in an area grazed at 1.35 acres/AUM compared to an area grazed at 3.25 acres/ AUM. After 22 years of grazing at this intensity, not only had species composition been altered but soil properties had been changed as well.

In a riparian zone continuously grazed season long, Orr (1960) found bulk density and macropore space to be significantly greater in grazed areas over exclosures. Differences in total pore space (both macro-and micro-pores) between grazed and exclosed areas were small because of a transformation of macropore spaces to micropore spaces by trampling. Macropore space is a more sensitive indicator of compaction or recovery from compaction than either micro or total pore space (Orr 1960).

Bryant et al. (1972) found increasing trampling pressure had an adverse effect on Kentucky bluegrass swards, particularly during the months of June and September. After one overwinter period, there was a significant difference in soil compaction between an area trampled by 120 cow trips over bluegrass plots and an area that was untrampled.

\section{Impacts of Herbage Removal}

Impacts of herbage removal can be divided into 2 categories according to vegetation structure: (1) utilization of herbaceous vegetation and subsequent impacts on species composition, species diversity, and biomass produced and (2) utilization of woody vegetation and subsequent impacts on foliage cover, structural height diversity and stand reproduction.

A major vegetation change that has taken place in mountain riparian systems of the Pacific Northwest is replacement of native bunchgrass with Kentucky bluegrass. It has successfully established itself as a dominant species in native bunchgrass meadows as a result of overgrazing by herbivores and subsequent site deterioration (Volland 1978).

Pond (1961), in Wyoming, found clipping native bunchgrass meadows every 2 weeks for 4 years caused a marked reduction in native sedges (Carex spp.), tufted hairgrass (Deschampsia caespitosa) and fostered the appearance of Kentucky bluegrass where it was not present before. Kauffman et al. (1983a) found that when grazing was halted in moist meadows, succession towards a more mesic/hydric plant community occurred. Exotic grasses such as meadow timothy (Phleum pratense) and forbs more attuned to drier environments were decreasing and were being replaced by native sedges and mesic forbs.

In central Oregon, Evenden and Kauffman (unpublished) compared plant communities on each side of a fence that was heavily grazed on one side and protected from grazing on the other. The grazed site was dominated by Kentucky bluegrass and Baltic rush (Juncus balticus), while the ungrazed site was dominated by panicled bullrush (Scirpus microcarpus). Twenty herbaceous species were recorded in the grazed area with 12 herbaceous species recorded in the ungrazed area. Dobson (1973) also found an increase in species numbers due to grazing in a riparian zone in New Zealand. He concluded the effect of grazing had been to open up the vegetation, creating more niches in which weeds could establish themselves. Hayes (1978) in central Idaho also observed that the abundance of forb species appeared to be higher in grazed areas than in pristine areas.

The impact of cattle on herbaceous productivity in riparian zones has been examined along several streamsides in the western United States. Duff (1979), Gunderson (1968), Kauffman et al. (1983a), Marcuson (1977), McLean et al. (1963), and Pond (1961) found either decreases in biomass due to herbage removal or increases in biomass due to cessation of grazing in riparian ecosystems.

Kauffman et al. (1983a) compared grazed and ungrazed responses on 10 riparian plant communities in northeastern Oregon from 1978 to 1980 . Three of 10 communities displayed significant standing biomass differences. Production in ungrazed moist meadows dominated by Kentucky biomass, meadow timothy, and sedges was significantly less after 2 years of rest compared to grazed meadows but was not significantly different after 3 years of rest. Standing biomass in a Douglas hawthorn-dominated community and in a Kentucky bluegrass-dominated community was significantly greater in ungrazed stands compared to grazed stands after 3 years. Conversely, Volland (1978) could find no significant differences in biomass between a Kentucky bluegrass meadow grazed annually and one that had been rested for 11 years.

Effect of herbivory on shrub and tree production is a critical impact in riparian ecosystems, because of the importance of the woody vegetation to wildlife habitat and its dominant influence in altering the riparian microclimate. While mature vegetation approaches senescence, excessive grazing pressures have prevented the establishment of seedlings, thus producing an even-aged nonreproducing vegetative community (Carothers 1977, Glinski 1977).

The effects of excessive herbivore use on woody vegetation bordering streamsides can generally be termed as negative. Knopf and Cannon (1982) found that cattle significantly altered the size, shape, volume, and quantities of live and dead stems of willows. Cattle grazing was also found to influence the spacing of plants and the width of the riparian zone. Marcuson (1977) found shrub production to be 13 times greater in an ungrazed area than in a severely overgrazed area. Cover was $82 \%$ greater in the natural area. On a stream rested from continuous grazing for 10 years, Claire and Storch (unpublished) found alders ( $A$ lnus sp.) and willows (Salix spp.) provided $75 \%$ shade cover over areas that had been devoid of shrub canopy cover before exclosure. Similar herbivore-woody vegetation relations have been reported by Crouch (1978), Davis (1982), Duff (1979), Evenden and Kauffman (1980), Gunderson (1968), and Kauffman (1982).

\section{Management of Riparian Ecosystems}

Recognizing and understanding the impacts on the streamsides which resulted from all previous land use practices is a prerequisite to streamside planning (Claire and Storch unpublished). Because of their small extent, riparian zones in the past were considered "sacrifice areas"(Oregon-Washington Interagency Wildlife Council 1978, Skovlin et al. 1977). Riparian vegetation has been intensively used by livestock over several decades causing a reduction in the productivity of fish and wildlife habitats and degrading water quality as well as promoting increases in flow fluctuations (Oregon-Washington Interagency Council 1978).

Platts (1979) indicated that riparian ecosystems are the most critical zones for multiple-use planning and offer the most challenge for proper management; therefore, stream habitats should be identified as separate management units from the surrounding upland ecosystems. Even among riparian zones the need to identify and classify them adequately is important for proper stewardship of these systems (Claire and Storch unpublished, Platts 1978, 1979).

However, there have been few attempts to come up with a viable classification scheme of riparian vegetation that is feasible for land 
management activities (Cowarden 1978, Norton et al. 1981, Padgett 1982, Pase and Layser 1977, Tuhy and Jenson 1982). The major problem has been the lack of successional knowledge to formulate classification schemes based upon potential climax communities. Other problems have been the lack of continuity of terminology. For example, terms such as riparian dominance type (Padgett 1982), community type (Tuhy and Jenson 1982), and riparian type (USFS-R-4 file data) have all been used to define the basic unit of land which supports a riparian community.

Land management agencies responsible for managing livestock grazing have not adequately considered the influence of grazing on the other uses and users of riparian ecosystems (Platts 1979). Often what is good range or timber management (in short-term economic terms) is not good riparian or stream management (Platts 1979). On the other hand, it has been suggested that proper stream management practices that protect stream banks from damage also improve the potential for riparian zones to enhance fisheries, wildlife, and livestock uses (Gunderson 1968, Marcuson 1977).

Methods discussed for riparian zone rehabilitation include exclusion of livestock grazing, alternative grazing schemes, changes in the kind or class of animals, managing riparian zones as "special use pastures," in-stream structures and several basic range management practices (eg. salting, alternative water sources, fencing, range riders, etc.).

The use of instream structures as a method of riparian rehabilitation has met with some success where instream structures are combined with rest from livestock grazing (Duff unpublished, Heede 1977). Bowers et al. (1979) indicated that some instream structures (e.g., trash catchers, gabions, small rock dams, individual boulder placement, rock jetties, and silt log drops) could serve the dual purpose of increasing the water table in areas of former wet meadows as well as improving salmonid habitat.

Heede (1977), combining rest from grazing with construction of check dams, obtained vegetation cover improvements, a change from an ephemeral stream flow to a perennial flow and a stabilization of gully erosion.

After losing 23 out of 26 instream structures in a grazed area in Utah, Duff (unpublished) suggested that stream improvement structures cannot work effectively to restore pool quality and streambank stability as long as livestock grazing continued. Keller et al. (1979) in Idaho found that rest from grazing negated the need for artificial instream structures intended to enhance trout production for stream ecosystems. Kimball and Savage (in Swan 1979) found aquatic ecosystems can be restored through intensive livestock management at a lower cost than through installation of instream improvement structures.

Grazing systems have achieved some success in riparian rehabilitation and much success in riparian ecosystem maintenance. The damage caused by heavy season or yearlong grazing is well documented (Evans and Krebs 1977, Gunderson 1968, Marcuson 1977, Severson and Boldt 1978). It appears that rest-rotation grazing schemes and/or specialized grazing schemes in which riparian zones are treated as special use pastures have been the most successful.

Hayes (1978), in Idaho, stated that species composition appeared to be improved under a rest-rotation grazing system and bank sloughoff occurrences were not increased if utilization was under $60 \%$. In other Idaho mountain grazing studies, Platts (1982) stated that when rest-rotation strategies call for livestock to utilize riparian vegetation at a rate of $65 \%$ or more, some riparian habitat alteration occurs. He also indicated that riparian alteration may be insigificant when utilization is equal to $25 \%$ or less.

Claire and Storch (unpublished) found a rest-rotation system to be favorable for achieving desired streamside management objectives if 1 year's rest out of 3 is included in the scheme.

Davis (1982), in Arizona, found that a four-pasture rest-rotation system was a cost-effective and successful method for rehabilitation of the riparian resource when each pasture received spring- ummer rest for 2 years out of 3 . On 2 grazing allotments, cottonwood and willows had a mean increase from 78 plants/ ha to 2,616 plants/ha, 2 years after implementation of the system. A restrotation system also obtained a very favorable response for vegetation surrounding a livestock pond in South Dakota (Evans and Krebs 1977).

Criticism of rest-rotation systems includes reports that objectives for herbaceous vegetation were not being achieved within desired time limits (Storch 1979), and that rest-rotation systems may increase trailing and trampling damage, causing streambank erosion and instability (Meehan and Platts 1978).

Fencing and managing riparian zones separately from terrestrial upland sites as special use pastures has been shown to be an adequate multiple use system of riparian zone management (Kauffman 1982, Winegar 1977). Simulated grazing of a fenced riparian zone annually after August 1 had no measurable effect on production or species composition in riparian mcadows, contrasted to decreased production and composition in a simulated season-long scheme in northcentral Wyoming (Pond 1961).

Kauffman (1982) suggested that positive characteristics of a late season grazing scheme on a riparian zone in Oregon included increased livestock production, good plant vigor and productivity, minimal soil disturbance, and minimal short-term disturbance to wildlife populations dependent on riparian ecosystems.

Another grazing system for fenced riparian zones includes winter grazing, where possible, to minimize damage (Severson and Boldt 1978). For riparian meadows dominated by Kentucky bluegrass, Volland (1978) recommended an initial year's rest, then late spring grazing alternated with late fall grazing to discourage flowering, increase tiller development, maintain plant vigor, and maximize productivity.

Changes in the kind or class of animal as well as selective culling and breeding may be another positive tool for riparian rehabilitation or maintenance. Roath (1980) found that cattle exhibited distinctive home range patterns in which certain groups of cattle preferred upland sites and groups preferred riparian sites. As forage became limiting on stream bottoms, some cattle actually decreased intake rather than move away from the riparian zone. Selective culling of these cattle and replacing them with those that prefer uplands may be beneficial for the livestock operator as well as for the riparian zone.

Platts (1982) stated that because sheep grazing on public lands is usually controlled by the use of herders, it may be possible to graze a watershed without exerting direct significant influence on riparian habitats. May and Davis (1982) suggested that sheep have been shown to exert a lesser influence on certain riparian and aquatic ecosystems and converions back to a sheep operation may be necessary to improve some riparian areas.

The most successful riparian management alternative on public lands to date has been intensive livestock management by permit holders (Storch 1979). Herding livestock on a somewhat daily basis has been successful in limiting the number of livestock that visit streambottoms and improving utilization of upland areas. Proper stewardship of riparian ecosystems is, in effect, money in the bank for the floodplain rancher (Marcuson 1977). Proper management of riparian zones mcans decreased streambank erosion and floodplain losses (Duff 1979, Gunderson 1968, Marcuson 1977), increased forage production (Evans and Krebs 1977, Pond 1961, Volland 1978), and an increased wildlife and fisheries resource (Buttery and Shields 1975, Duff 1979, Tubbs 1980, Van Velson 1979).

In conclusion, public grazing lands must be managed on a true multiple use basis that recognizes and evaluates the biological potential of each ecological zone in relation to the present and future needs of our society as a whole (Behnke et al. unpublished). Management strategies that recognize all resource values must be designed to maintain or restore the integrity of riparian communities (Behnke et al. unpublished). 


\section{Literature Cited}

Alderfer, R.B., and R.R. Robinson. 1949. Runoff from pastures in relation to grazing intensity and soil compaction. J. Amer. Soc. Agron. 39:948-958.

Ames, C.R. 1977. Wildlife conflicts in riparian management: Grazing. In: Importance, Preservation and Management of Riparian Habitat. USDA Forest Serv. Gen. Tech. Rep. RM-43:39-51.

Behnke, R.J., and M. Zarn. 1976. Biology and management of threatened and endangered western trouts. USDA Forest Serv. Gen. Tech. Rep. RM-28.

Behnke, R.J., and R.F. Raleigh. 1978. Grazing and the riparian zone: Impact and management perspectives. p. 184-189. In: Strategies for Protection and Management of Floodplain Wetlands and Other Riparian Ecosystems. USDA Forest Serv. GTR-WO-12.

Behnke, R.J., and thirteen others. Unpublished. Livestock interactions with fish and their environments. In: Symposium on Livestock Interactions with Wildlife, Fish and Their Environments. Sparks, Nevada. May 1977. On file at University of California, Davis.

Bowers, W., B. Hosford, A. Oakley, and C. Bond. 1979. Wildlife habitats in managed rangelands-The Great Basin of southeastern Oregon: Native Trout. USDA Forest Serv. Gen. Tech. Rep. PNW-84.

Bryant, F.T., R.E. Blaser, and J.R. Peterson. 1972. Effect of trampling by cattle on bluegrass yield and soil compaction of a Meadowville Loam. Agron. J. 64:331-334.

Buckhouse, J.C., J.M. Skovlin, and R.W. Knight. 1981. Streambank erosion and ungulate grazing relationships. J. Range Manage. 34:339-340.

Burgess, H.H., H.H. Prince, and D.L. Trauger. 1965. Blue-winged teal nesting success as related to land usc. J. Wildl. Manage. 21:89-95.

Busby, F.E. 1979. Riparian and stream ecosystems, livestock grazing, and multiple-use management. p. 6-13. In: Grazing and Riparian/Stream Ecosystems. Trout Unlimited.

Buttery, R.F., and P.W. Shield. 1975. Range management practices and bird habitat values. In: Symposium on Management of Forest and Range Habitats for Non-game Birds. USDA Forest Serv. Gen. Tech. Rep. W0-1

Campbell, A.G., and J.F. Franklin. 1979. Riparian vegetation in Oregon's western Cascade Mountians: composition, biomass, and autumn phenology. Coniferous Forest Biome, Ecosystem Analysis Studies, U.S. 1.B.P. Prog. Bull. N. 14.

Carothers, S.W. 1977. Importance, preservation and management of riparian habitat: an overview. In: Importance, Preservation and Management of Riparian Habitat. USDA Forest Serv. Gen. Tech. Rep. RM-43:2-4.

Carothers, S.W., R.R. Johnson, and S.W. Aitchison. 1974. Population structure and social organization of southwestern riparian birds: Amer. Zool. 14:97-100.

Carothers, S.W., and R.R. Johnson. 1975. Water management practices and their effects on non-game birds in range habitats. In:Symposium on Management of Forest and Range Habitats for Non-game Birds. USDA Forest Serv. Gen. Tech. Rep. W0:1:210-222.

Chapman, D.W., and E. Knudsen. 1980. Channelization and livestock impacts on salmonid habitat and biomass in western Washington. Trans. Amer. Fish Soc. 109.

Claire, E.W., and R.L. Storch. Unpublished. Streamside management and livestock grazing: an objective look at the situation. In; Symposium on Livestock Interactions with Wildlife, Fish, and Their Environments. Sparks, Nevada. May 1977. On file at University of California, Davis.

Cowardin, L.M. 1978. Wetland classification in the United States. J. Forest. 76:666-668.

Crouch, G.L. 1978. Effect of protection from livestock on bottomland wildlife habitat in northeastern Colorado. p. 118-125. In: Proc. Lowland River and Stream Habitat Symposium. Greeley, Colo.

Crouch, G.L. 1982. Wildlife on ungrazed and grazed bottomlands on the South Platte River in northeastern Colorado. p. 186-197. In: WildlifeLivestock Relationships Symposium: Proc. 10. Univ. of Idaho Forest, Wildlife and Range Exp. Sta., Moscow.

Cummins, K.W. 1974. Structure and function of stream ecosystems. Bioscience. 24:631-641.

Cummins, K.W., and G.L. Spengler. 1978. Stream ecosystems. Water Spectrum. 10:1-9.

Dahlem, E.A. 1979. The Mahogany Creek watershed-with and without grazing p. 31-35. In: Proc., Forum-Grazing and Riparian/Stream Ecosystems. Trout Unlimited, Inc.

Dambach, C.A., and E.E. Good. 1940. The effect of certain land use practices on populations of breeding birds in southwestern Ohio. J. Wildlife Manage. 4:63-76.
Davis, J.W. 1982. Livestock vs. riparian habitat management-there are solutions. p. 175-184. In: Wild life-Livestock Relationships Symposium: Proc. 10. Univ. of Idaho Forest, Wildlife and Range Exp. Sta. Moscow.

DeBano, L.F. 1977. Influence of forest practices on water yield, channel stability, erosion, and sedimentation in the Southwest. In: Proc. Soc. Amer. Forest. 1977 Nat. Conv., Soc. Amer. Forest., Washington, D.C.

Dobson, A.T. 1973. Changes in the structure of riparian community as the result of grazing. Proc. New Zealand Ecol. Soc. 20:58-64.

Duff, D.A. 1979. Riparian habitat recovery on Big Creek, Rich County, Utah. p. 91. In: Proc., Forum-Grazing and Riparian/Stream Ecosystems. Trout Unlimited, Inc.

Duff, D.A. Unpublished. Livestock grazing impacts on aquatic habitat in Big Creek, Utah. In:Symposium on Livestock Interaction with Wildlife, Fisheries and Their Environments. Sparks, Nevada. On file at University of California, Davis.

Evans, Keith E., and Roger R. Krebs. 1977. Avian use of livestock watering ponds in western South Dakota. USDA Forest Serv. Gen. Tech. Rep. RM-35.

Evenden, A., and J.B. Kauffman. 1980. A preliminary investigation of two riparian ecosystems excluded from grazing in the Ochoco Mountains of central Oregon. Unpubl.

Everest, F.H., and W.R. Meehan. 1981. Forest management and anadromous fish habitat productivity: Tran. 46th North Amer. Wildlife and Natural Resources Conf. 1981. Wildlife Mgmt. Inst. Wash., D.C.

Ganskopp, D.C. 1978. Plant communities and habitat types of the Meadow Creek experimental watershed. M.S. Thesis. Oregon State University, Corvallis.

Glinski, R.L. 1977. Regeneration and distribution of sycamore and cottonwood: their ecology and conservation. In: Importance, Preservation and Management of Riparian Habitat. USDA Forest Serv. Gen. Tech. Rep. RM-43:116-123.

Gunderson, D.R. 1968. Floodplain use related to stream morphology and fish populations. J. Wildl. Manage. 32:507-514.

Hayes, F.A. 1978. Streambank and meadow condition in relation to livestock grazing in mountain meadows of central Idaho. M.S. Thesis, University of Idaho.

Heede, Burchard H. 1977. Case study of a watershed rehabilitation project: Alkali Creek, Colorado. USDA Forest Serv. Res. Pap. RM-189.

Henke, Merlin, and Charles P. Stone. 1978. Value of riparian vegetation to avian populations along the Sacramento River system. In:Strategies for Protection and Management of Floodplain Wetlands and Other Riparian Ecosystems. USDA Forest Serv. GTR-WO-12:228-235.

Hubbard, J.P. 1977. Importance of riparian ecosystems: biotic considerations. In: Importance, Preservation and Management of Riparian Habitat. USDA Forest Serv. Gen. Tech. Rep. RM-43:14-18.

Jahn, L.R. 1978. Values of riparian habitats of natural ecosystems. In: Strategies for Protection and Management of Floodplain Wetlands and Other Riparian Ecosystems. USDA Forest Serv. GTR-W0-12:157-160.

Johnson, R.R., L.T. Haight, and J.M. Simpson. 1977. Endangered species vs. endangered habitats: a concept. In: Importance, Preservation and Management of Riparian Habitat. USDA Forest Serv. Gen. Tech. Rep. RM-43:68-79.

Johnson, S.R., H.L. Gary, and S.L. Ponce. 1978. Range cattle impacts on stream water in the Colorado Front Range. USDA Forest Serv. Res. Note RM-359.

Kauffman, J.B. 1982. Synecological effects of cattle grazing riparian ecosystems. M.S. Thesis. Oregon State University, Corvallis.

Kauffman, J.B., W.C. Krueger, and M. Vavra. 1982. Impacts of a late season grazing scheme on nongame wildlife habitat in a Wallowa Mountain riparian ecosystem. p. 208-220. In: Wildlife-Livestock Relationships Symposium. March 1981. Cour d'Alene, Ida.

Kauffman, J.B., W.C. Krueger, and M. Vavra. 1983a. Effects of cattle grazing on riparian plant communities. J. Range Manage. 36:685-691.

Kaufiman, J.B., W.C. Krueger, and M. Vavra. 1983b. Impacts of cattle grazing streambanks in northeastern Oregon. J. Range Manage. 36:683685.

Kauffman, J.B., W.C. Krueger, and M. Vavra. 1984. Ecology and plant communities of the riparian area associated with Catherine Creek in northeastern Oregon. Oregon State Univ. Agr. Exp. Sta. Tech. Bull. In press.

Keller, C., L. Anderson, and P. Tappel. 1979. Fish habitat changes in Summit Creek, Idaho, after fencing. p. 46-52. In: Proc., Forum-Grazing and Riparian/Stream Ecosystems. Trout Unlimited, Inc.

Kennedy, C.E. 1977. Wildlife conflicts in Riparian Management: Water. In: Importance, Preservation and Management of Riparian Habitat. USDA Forest Serv. Gen. Tech. Rep. RM-43:52-58. 
Kirch, L.M., and K.F. Higgins. 1976. Upland sandpiper nesting and management in North Dakota. Wildl. Soc. Bull. 4:16-20.

Knoph, F.L., and R.W. Cannon. 1982. Structural resilience of a willow riparian community to changes in grazing practices. p. 198-2097. In Wildlife-Lifestock Relationships Symposium: Proc. 10. Univ. of Idaho Forest, Wildlife and Range Exp. Sta. Moscow.

Li, Ruh-Ming, and H.W. Shen. 1973. Effect of tall vegetation and flow sediment. J. Hydraulics Div., ASCE, Vol. 9, No. HY5, Proc. Paper 9748.

Lorz, H.W. 1974. Ecology and management of brown trout in Little Deschutes River. Fishery R8. Rep. No. 8. Ore. Wildl. Comm., Corvallis.

Marcuson, P.E. 1977. The effect of cattle grazing on brown trout in Rock Creek, Montana. Fish and Game Fed. Aid Pro. F-20-R-2111 a.

May, B., and B. Davis. 1982. Practices for livestock grazing and aquatic habitat protection on western rangelands. p. 271-278. In: WildlifeLivestock Relationships Symposium: Proc. 10. Univ. of Idaho Forest, Wildlife and Range Exp. Sta. Moscow.

McLean, A., H.H. Nicholson, and A.I. Van Ryswyk. 1963. Growth productivity and chemical composition of a subalpine meadow in interior British Columbia. J. Range Manage. 16:235-240.

McKee, J.E., and K.W. Wolf., eds. 1963. Water quality criteria. California State Water Resour. Control Board, Pub. 3-A (revised). Sacramento.

Meehan, W.R., and W.S. Platts. 1978. Livestock grazing and the aquatic environment. J. Soil and Water Conserv. 33:274-278.

Meehan, W.R., F.J. Swanson, and J.R. Sedell. 1977. Influences of riparian vegetation on aquatic ecosystem with particular reference to salmonid fishes and their food supply. In: Importance, Preservation and Management of Riparian Habitat. USDA Forest Serv. Gen. Tech. Rep. RM-43:137643.

Mosconi, S.L., and R.L. Hutto. 1982. The effects of grazing on land birds of a western Montana riparian habitat. p. 221-233. In: Wildlife-Livestock Relationships Symposium: Proc. 10. Univ, of Idaho Forest, Wildlife, and Range Exp. Sta. Moscow.

Norton, B.E., J.S. Tuhy, and S. Jenson. 1981. Riparian classification for the Grey's River, Wyoming. USDA Forest Serv. Regional Office Contract Rep. Ogden, Utah.

Odum, E.P. 1971. Fundamentals of Ecology - Third edition. W.B. Saunders Co. Philadelphia, Pa.

Odum, E.P. 1978. Opening address: Ecological importance of the riparian zone. In: Strategies for Protection and Management of Floodplain Wetlands and Other Riparian Ecosystems. USDA Forest Serv. GTR-WO-12.

Oregon-Washington Interagency Wildlife Council. 1978. Managing riparian zones for fish and wildlife in eastern Oregon and eastern Washington. Unpub.

Orr, H.K. 1960. Soil porosity and bulk density on grazed and protected Kentucky bluegrass range in the Black Hills. J. Range Manage. 13:80-86.

Overmire, T.G. 1963. The effects of grazing upon habitat utilization of the dickcissol (Spiza americana) and Bell's vireo (Vireo bellii) in northcentral Oklahoma. PhD Thesis. Oklahoma State Univ., Stillwater.

Owens, R.A., and M.T. Myers. 1973. Effects of agriculture upon native passerine birds on an Alberta fescue grassland. Can. J. Zool. 51:697-713.

Padgett, W.G. 1982. Ecology of riparian plant communities in southern Malheur National Forest. M.S. Thesis. Oregon State Univ., Corvallis.

Pase, C.E., and E.F. Layser. 1977. Classification of riparian habitat in the southwest. In: Importance, Preservation, and Management of Riparian Habitat: A Symposium. USDA Forest Serv. Gen. Tech. Rep. RM-43:3547. Fort Collins, Colo.

Patton, D.R. 1977. Riparian research needs. In: Importance, Preservation and Management of Riparian Habitat. USDA Forest Serv. Gen. Tech. Rep. RM-43:80-82. Fort Collins, Colo.

Paulsen, H.A. Jr. 1969. Forage value on a mountain grassland aspen range in western Colorado. J. Range Manage. 22:102-107.

Peterson, S.R. 1980. The role of birds in western communities. In: Management of Western Forests and Grasslands for Nongame Birds. USDA Forest Serv. Gen. Tech. Rep. 1NT-86:6-12.

Platts, W.S. 1978. Livestock interactions with fish and their environments: Tran. 43rd North Amer. Wildlife and Natural Resources Conf. 1978. Wildlife Manage. Inst. Washington, D.C.

Platts, W.S. 1979. Livestock grazing and riparian/stream ecosystems. p. 39-45. In: Proc., Forum-Grazing and Riparian/Stream Ecosystems. Trout Unlimited, Inc.

Platts, W.S. 1981. Influence of forest and rangeland management on anadromous fish habitat in western North America. Effects of livestock grazing. USDA Forest Serv. Gen. Tech. Rep. PNW-124.
Platts, W.S. 1982. Sheep and cattle grazing strategies on riparian-stream environments. p. 251-270. In: Wildlife-Livestock Relationships Symposium: Proc. 10. Univ. of Idaho Forest, Wildlife and Range Exp. Sta. Moscow.

Pond, F.W. 1961. Effect of three intensities of clipping on the density and production of meadow vegetation. J. Range Manage. 14:34-38.

Rauzi, F., and C.L. Hanson. 1966. Water intake and runoff as affected by intensity of grazing. J. Range Manage. 19:351-356.

Reid, E.H., and G.D. Pickford. 1946. Judging mountain meadow range condition in eastern Oregon and eastern Washington. USDA Circ. No. 748.

Reynolds, T.D., and C.H. Trost. 1980. The response of native vertebrate populations to crested wheatgrass planting and grazing by sheep. J. Range Manage. 33:122-125.

Roath, L.R. 1980. Cattle grazing and behavior on a forested mountain range and their relationship to acute dietary bovine pulmonary emphysema. PhD Thesis. Oregon State University, Corvallis.

Roath, L.R., and W.C. Krueger. 1982. Cattle grazing influence on a mountain riparian zone. J. Range Manage. 35:100-104.

Ryder, R.A. 1980. Effects of grazing on bird habitats. In: Management of Western Forests and Grasslands for Nongame Birds. USDA Forest Serv, Gen. Tech. Rep. INT-86:51-56.

Sands, A., and G. Howe. 1977. An overview of riparian forests in California: Their ecology and conservation. In: Importance, Preservation and Management of Riparian Habitat. USDA Forest Serv, Gen. Tech. Rep. RM-43:98-115.

Schumm, S.A., and David F. Meyer. 1979. Morphology of alluvial rivers of the Great Plains p. 9-15. In: Riparian and Wetland $\mathrm{Habitats}$ of the Great Plains: Proc. of the 3 lst Annual Meeting, Great Plains Agr. Counc. Pub. No. 91.

Sedell, J., F.J. Triska, J. Hall, N. Anderson, and J. Lyford. 1974. Sources and fates of organic inputs in coniferous forest streams. p. 57-59. In. R.H. Waring (ed.) Integrated research in the coniferous forest biome. Proc. AIBS Symp. Conif. Forest Ecosystems. Conif. Forest Biome Bull.

Severson, K.E., and C.E. Boldt. 1978. Cattle, wildlife, and riparian habitats in the western Dakotas. p. 94-103. In: Management and Use of Northern Plains Rangeland. Reg. Rangeland Symp., Bismark, N. Dak.

Skovlin, J. 1967. Fluctuations in forage quality on summer range in the Blue Mountains. USDA Forest Serv. PNW-Res. Pap. 44

Skovlin, J.M., W.R. Meehan, J.C. Buckhouse, and M. Vavra. 1977. A method of study for determining the influence of grazing on riparian and aquatic habitats in the Blue Mountains of eastern Oregon and Washington.

Smith, C.C. 1940. The effect of overgrazing and erosion upon the biota of the mixed-grass prairie of Oklahoma. Ecol. 21:381-397.

Stevens, L., B.T. Brown, J.M. Simpson, and R.R. Johnson. 1977. The importance, Preservation and Management of Riparian Habitat. USDA Forest Serv, Gen. Tech. Rep. RM-43:156-164.

Storch, R. 1979. Livestock/streamside management programs in eastern Oregon. p. 56-59. In: Proc. Forum-Grazing and Riparian/Stream Ecosystems. Trout Unlimited, Inc.

Swan, B. 1979. Riparian habitat-the cattleman's viewpoint. p. 4-6. In: Proc., Forum-Grazing and Riparian Stream Ecosystems. Trout Unlimited, Inc.

Swanson, F.J., S.V. Gregory, J.R. Sedell, and A.G. Campbell. 1982. Land-water interactions: The riparian zone. In: Analysis of Coniferous Forest Ecosystems in the Western United States. US/IBP Synthesis Series 14 Stroudsburg, $\mathrm{Pa}$. Hutchinson Ross Publishing $\mathrm{Co}$.

Thomas, J.W., C. Maser, and J.E. Rodiek. 1979. Wildlife habitats in managed rangelands - the Great Basin of southeastern Oregon. Riparian Zones. USDA Forest Serv. Gen. Tech. Rep. PNW-80.

Townsend, J.E., and P.J. Smith. 1977. Proc. of a seminar on improving fish and wildlife benefits in range management. U.S. Dept. Int. Fish and Wildl. Serv. Prog. Washington D.C. FWS/OBS-77/1.

Tubbs, A.A. 1980. Riparian bird communities of the Great Plains. In: Workshop Proc.-Management of Western Forests and Grasslands for Nongame Birds. USDA Forest Serv. Gen. Tech. Rep. INT-86:403-418.

Tuhy, J.S., and S. Jenson. 1982. Riparian classification for the upper Salmon/Middle Fork Salmon Rivers Idaho. USDA Forest Serv. Regional Office Contract Rep. 195 p. Ogden, Utah.

Van Velson, R. 1979. Effects of livestock grazing upon rainbow trout in Otter Creek p. 53-56. In: Proc., Forum-Grazing and Riparian/Stream Ecosystems. Trout Unlimited, Inc.

Volland, L.A. 1978. Trends in standing crop and species composition of a rested Kentucky bluegrass meadow over an 11 -year period. p. 525-529. In: D.N. Hyder (ed.) Proc. Ist Int. Rangeland Congr. Denver, Colo. 
Wauer, R.H. 1977. Significance of Rio Grande Riparian systems upon the avifauna. In: Importane, Preservation and Management of Riparian Habitat. USDA Forest Serv. Gen. Tech. Rep. RM-43:165-174.

Wiens, J.A. and M.I. Dyer. 1975. Rangeland avifaunas: their composition, energetics and role in the ecosystem. In; Symposium on Management of
Forest and Range Habitats for Nongame Birds. USDA Forest Serv. Gen. Tech. Rep. WO-1:146-182.

Winegar, H.H. 1977. Camp Creek channel fencing-plant, wildlife and soil and water response. Rangeman's J. 4:10-12. 